\title{
Perfuratividades: máquinas de guerra sonora e táticas curriculantes com o funk em um cotidiano escolar
}

\section{Piercing action: sound war machines and curriculum tactics with funk in school every day life Performatividad: Máquinas de guerra sonoras y tácticas de currículo con funk en el cotidiano escolar}

Augusto Flávio ${ }^{1}$

Rosane Meire de Vieira de Jesus ${ }^{2}$

DOI: http://dx.doi.org/10.20435/serie-estudos.v26i58.1580

\begin{abstract}
Resumo: Eis uma amostra parcial da paisagem de uma pesquisa cujo enquadramento em questão são as perfurações que podem devir curriculantes nos agência/mentos musicais disseminados em cotidianos escolares. A noção de currículo que é operada ao longo da narrativa é performativa, o que implica pensar o seu discurso como um ato de poder e compor sua escritura com procedimentos de familiaridade musical, para produzir, em vez de um documento disciplinar sobre música, uma partitura curricular, partitura que também se assemelha a um cartograma, é rizoma, e também um convite a uma performance improvisativa de pesquisa nas ambulações com os argumentos da investigação pós-qualitativa, em encontros com os conceitos de deriva, experiência, e acontecimento. E foi justamente da perfuração sonora do no agência/mento funk "Bum Bum Tam Tam" de MC Fioti, no pátio de um colégio, e das simbioses entre estudantes e esse evento, suas plagicombinações e mixagens políticas, formasfluxos, que a pesquisa tentou partiturografar a emergência de algumas conceituações em rumo teorizante para uma ecologia estética em currículos.
\end{abstract}

Palavras-chave: currículo; cotidiano; pesquisa improvisativa.

Abstract: Here is a partial sample of the landscape of a research whose framing in question are
the drilling that can become curricular in musical agency/ing disseminated in school everyday life.
The notion of curriculum that is operated throughout the narrative is performative, which implies
thinking its discourse as an act of power and composing its writing with procedures of musical
familiarity, to produce, instead of a disciplinary document on music, a curricular score, a score that
also resembles a cartogram, is a rhizome, and also an invitation to an improvised performance of

${ }^{1}$ Universidade Federal da Bahia (UFBA), Salvador, Bahia, Brasil.

${ }^{2}$ Universidade do Estado da Bahia (UNEB), Conceição do Coité, Bahia, Brasil. 
research in ambulations with the arguments of post-qualitative investigation, in meeting with the concepts of drift, experience, and event. And it was precisely from the sound drilling of the funk agency/ing "Bum Bum Tam Tam" by MC Fioti, in a school yard, and the symbiosis between students and this event, their plagicombinations and political mixes, forms-flows, that the research tried to score action to emergence of some conceptualizations in theorizing direction for an aesthetic ecology in curricular.

Keywords: curriculum; everyday life; improvisative research.

Resumen: He aquí una muestra parcial del panorama de una investigación cuyo marco en cuestión son las perforaciones que pueden convertirse en currículos, en agencia/mientos musicales difundidos en el cotidiano escolar. La noción de currículo que se opera a lo largo de la narrativa es performativa, lo que implica pensar su discurso como un acto de poder y componer su escritura con procedimientos de familiaridad musical, para producir en lugar de un documento disciplinar sobre música; una partitura curricular. Partitura que se asemeja a un cartograma, un rizoma, una invitación a una performance improvisativa en la búsqueda de ambulaciones, con los argumentos de la investigación post-cualitativa, en encuentros con los conceptos de deriva, experiencia y acontecimiento. Y fue precisamente a partir de la perforación sonora del agencia/ miento funk "Bum Bum Tam Tam", de MC Fioti (2017), en el patio de una escuela, y la simbiosis entre los estudiantes y este evento, sus plagicombinaciones y mezclas políticas, formasflujos, que la investigación trató de realizar una partirturografia (partitura cartográfica) en las emergencias de algunas conceptualizaciones en la dirección teorizante de una ecología estética en el currículo.

Palabras clave: currículo; cotidiano; investigación improvisativa.

\section{PERFURAÇÕES INTRODUTÓRIAS}

As mal traçadas linhas que se seguem compõem a trama parcial de uma pesquisa no âmbito de um Mestrado Profissional em Educação e Diversidade na Universidade do Estado da Bahia (UNEB) - Campus XIV, Território do Sisal, sertão de Alembaía, acolhida pelo Grupo de Pesquisa FEL - Formação, Experiência e Linguagens, entre os anos da graça de 2018 e 2020, realizada com estudantes de um colégio público de séries finais do ensino fundamental e ensino médio, localizado no perímetro urbano do município de Conceição do Coité, BA.

A parcialidade do que aqui será apresentado, contudo, não é apenas uma escolha aleatória, embora parta de uma premissa deliberadamente randômica, recurso que remete aos procedimentos de samplear e mixar a escritura dissertativa como poderia fazer um disc jockey, mais conhecido nos cotidianos como DJ (deejay), e assim se fez por inspiração na "estética do plágio" do músico iraraense Tom Zé (1999), e no insight performativo para a teoria curricular dado por Thiago Ranniery (2016), Alice Casimiro Lopes e Elizabeth Macedo (2011), de onde se 
partiu em digressão para pensar que, em vez de um currículo sobre música, a investigação poderia se debruçar sobre um currículo cuja composição fosse musical, uma partitura curricular, e é nesse sentido que o sample (mostra) da pesquisa é, nesses termos, consistente com a noção de plagicombinação.

O conceito em devir de plagicombinar, que na música reputa a um alfabeto sonoro em blocos de sensações nos samples da memória, é o que se pode aproximar na acepção cotidianista a colagens, "táticas [...] que organizam ao mesmo tempo uma rede de relações, 'bricolagens' poéticas e um reemprego das estruturas comerciais" (CERTEAU, 2014, p. 42). As insinuações de uma certa economicidade que se esboçam em tal paisagem conceitual não são casuísticas, pode-se argumentar a efeito que, em primeira monta, a plagicombinação é um programa que inflete para uma economia das narrativas, conquanto ainda se possa suplementar a isso com base nos argumentos de Tom Zé (1999), uma superposição de características de hibridismo cultural, que, por operações de mixagem, acedem a uma política de negociação estética contingente entre ritmos periféricos e os cânones clássicos, especulando com Homi Bhabha (2013), bem como uma aliança ao modo performativo de Judith Butler (2018), uma ação de coletividades, política e transitória, entre corporalidades que compartilham territorialidades urbanas precárias, o samba, funk e o hip-hop, os ritmos do gueto, as rimas da periferia e o batidões da favela, que se insurgem contra moralidade asséptica dos bons costumes e contra a predação e barbárie perpetradas pela racionalidade neoliberal.

Introduzir essas conceituações se prestou a situar a forma plagicombinada como emergiu o problema da pesquisa, que vazou incialmente dos samples das nossas memórias cotidianas com a música, aliadas às nossas experiências de corpo conectadas ecologicamente ao seu percurso tecnológico, para enfim nos perguntar localmente: que acontecimentos em simbioses com a música poderiam passar a perfurações curriculantes em um cotidiano escolar?

As próximas seções tentarão se imiscuir por alguns desses furos, e as formasfluxos mixadas que deles e por entre esses, vertem.

\section{PERFORMANCE IMPROVISATIVA DE PESQUISA}

Antes de adentrar mais propriamente nas perfurações espaçadas nos cotidianos escolares em questão, seria oportuno perfazer um transbordo a respeito 
das performances do corpo que pesquisa e dos corpos pesquisados. É dita performance extracotidiana (BARBA, 1994), não que esteja fora dos cotidianos, mas ao ser operada nos cotidianos pressupõe uma preparação de corpo anterior, um extra, uma experiência acumulada e um estado intermitente entre poupar e o esbanjar de energia, ora à deriva, ora em vigília absoluta.

A performance improvisativa, pois, surge na forma de atos performativos de improvisação; uma experiência imanente que adere ao corpo, em plano rizomático, despido da estampa representativa, é um ato "[...] dirigido a um certo ambiente territorializável no próprio ato" (COSTA, 2018, p. 177), a consistência do improviso aí reside nas sobreposições e simbioses entre o corpo organizado e corpos sem órgãos, posto que um e uns outros produzem seus próprios limites, seja pela responsividade daquele, seja pelos samples biográficos que se dispersam sequenciados nesses, perspectiva com óbvia inspiração cartográfica (DELEUZE; GUATTARI, 2011a; 2012a).

Se as sugestões anteriores buscam realocar as circunstâncias para o corpo que pesquisa com os cotidianos, o encontro com os argumentos pós-qualitativos (ST. PIERRE, 2018; 2019) precipitou a necessidade de um reposicionamento ontológico inclinada pela suposição de que o sujeito da tradição humanista-qualitativa, ao ingressar no território de consistência pós-estrutural, movimenta-se de maneira sobejamente problemática; a considerar ao menos o sistema conceitual de Mil Platôs, Gilles Deleuze e Félix Guattari (2011a), são muito explícitos sobre os acontecimentos nesse planômeno adquirirem sua consistência na condição de individuações sem sujeito.

A alternativa, por conseguinte, foi produzir uma evaporação do sujeito e assumir que os acontecimentos que irrompessem com alguma densidade ontológica nos cotidianos escolares da pesquisa seriam tomados por agência/mentos, conceito enquanto arranjo coletivo, um mashup (mistura) por justaposição de dois conceitos adjacentes, agência e agenciamento (BHABHA, 2013; DELEUZE; GUATTARI, 2011a; 2011b). Certamente, ocorrem muitas aproximações entre ambos: uma noção política evidente; derivações sobre o desejo com origem na psicanálise; e travessias mais ao largo ou mais à margem pelas teorias performativa e das enunciações.

Resta, no entanto, uma liminaridade resguardada pela barra (/), o retorno do sujeito à condição de agente que, mesmo sem embargo da voz orgânica, pode virtualmente devir organizado pelo discurso; mesmo assim, é de se considerar 
que o discurso eventualmente se desterritorialize como ato de individuação. Nos agência/mentos, o sujeito evapotranspirado se remanesce acó ou acolá - e de algum modo nos cotidianos costuma retornar -, é como uma mancha enodoada, uma infiltração ontológica nos acontecimentos, um rastro na extensão conceitual construída por Derrida (1973), traço de um indício ôntico.

Por sugestão de Maria Tereza Esteban (2003), zarpou-se em direção ao conceito de deriva estrutural de Humberto Maturana (2001, p. 80), uma espécie de "[...] curso que se produz, momento a momento, nas interações do sistema e suas circunstâncias". Desse advento, foram singularizados dois movimentos sob o enunciado de Derivas Hacker: 1) deriva stalker, termo que nasce para designar a perseguição persistente de pessoas, mas que nos cotidianos digitais assume uma compleição pueril no ato de bisbilhotar os perfis alheios; 2) deriva gizmo (ou deriva por gadgets), que dispõe sobre uma contaminação narrativa praticada por apetrechos tecnológicos usados como instrumentos de navegação e coordenadas, a exemplo do Shazam, aplicativo para smartphones que permite identificar músicas desconhecidas que soam em um espaço-tempo.

Tais movimentos foram cuidadosamente submetidos ao crivo da "ética hacker"; velada pela estrita observância à privacidade (HIMANEN, 2010), mas se resguardado o anonimato, a pesquisa pode reivindicar "[...] liberdade para criar, liberdade para apropriar todo o conhecimento disponível e liberdade para redistribuir esse conhecimento sob qualquer forma e por qualquer canal escolhido pelo hacker" (CASTELLS, 2003, p. 42), ou melhor dizendo, pelo pesquisador.

O Grupo de Experiências (GE), de Iris Oliveira e Rosane de Jesus (2018), foi escolhido como dispositivo performático para captura de agência/mentos, pois foi inscrito em uma matriz acontecimental, entretanto, próxima à fenomenologia e à hermenêutica. Por esse motivo, optamos por uma desterritorialização mais acentuadamente pós-qualitativa do GE, quando o realocamos para o plano das experiências (DELEUZE; GUATTARI, 2010), cuja diferença consiste em produzir as circunstâncias para acontecimentos, tomar qualquer emergência coletiva com a música em um cotidiano como uma experiência em grupo; por exemplo, tropeçar em derivas com estudantes ao redor de um equipamento sonoro já é o acontecimento mesmo.

E, enfim, o que passou a ser designado por partiturografia é uma transcodificação do conceito de cartografia (DELEUZE; GUATTARI, 2011a). Fosse apenas uma 
renomeação, por si enredaria implicações locais. Apesar das analogias notórias, os códigos de um mapa certamente são distintos dos de uma partitura, as notas estão imantadas com uma expressividade acústica ausente nas coordenadas, mas acedem, além disso, a um deslocamento de enunciação, uma partitura curricular joga com a forma, é uma formafluxo, portanto impregnada por uma discursividade estética e micropolítica: plagicombinações e mixagens, mashups, reedições e remixes; filtragens e produção de ruídos.

\section{ARMAS DE PROJETIVIDADE SONORA E SUAS DERIVAÇÕES CURRICULANTES}

Distinguido por olhares durante um intervalo do colégio, como professor visitante, o pesquisador havia recebido o benefício de furar a fila da merenda. Perambulava entre os estudantes amontoados na cantina em busca de um local para se aquietar enquanto sorvia um prato de sopa. A cantina fora construída próxima a um dos muros escolares, e este, contíguo a uma rua relativamente movimentada nas imediações da prefeitura do município. Sentado no batente onde se ergue a caixa d'água, imerso em pensamentos, deslizava meio alheio pela turba de jovens quando começou a ouvir em efeito doppler ${ }^{3}$, vindo da rua, um carro que se aproximava espocando no grave com uma aparelhagem de som estilo paredão, um hit musical de MC Fioti (2017).

Não demorou e as performances eclodiram e se dispersaram em alguns tantos agência/mentos por ali. Embalados ao som do batidão funk, corpos se moviam na tentativa dissimulada de acompanhar o ritmo: mãos nos joelhos flexionados ajudavam a projetar a bunda e, ato contínuo, precipitavam-se à flor da pélvis; dedo indicador entre os dentes matraqueavam mudos os versos onomatopeicos do refrão: Vai com o bum bum tam tam / Vem com o bum bum tam tam / Vai mexe o bum bum tam tam / Vem desce o bum bum tam tam.

Sobreposta à paisagem anteriormente descrita, tomada como um Grupo de Experiência em derivas, outra performance se movia em paralelo, em

\footnotetext{
${ }^{3}$ Efeito que causa certa alteração nas frequências sonoras quando um emissor está em movimento, nesse espectro tornam-se mais acentuadamente audíveis as mais agudas, médias ou mais graves, conforme a distância e o deslocamento do emissor, exemplo comum se dá quando ouvimos ao longe a sirene de uma ambulância se aproximando em relação a nossa posição.
} 
que incontáveis orelhas desfilavam com pequenos autofalantes incrustrados, plugados a dispositivos móveis de comunicação e entretenimento. Alguns deles traspassavam e se fixavam nas conchas auditivas, outros pendiam dependurados em alargadores de aço nos lóbulos cartilaginosos, e chegavam a alcançar os ombros, "[...] colados no ouvido, estão ligados a ritornelos que foram produzidos longe, muito longe [...]" (GUATTARI, 1992, p. 169).

Um lance insólito está relacionado às práticas de consumo dos fones de ouvido nos cotidianos escolares observados. Sua aparência comum frequentava todos os espaços, e não somente durante os intervalos ou transportados através dos corredores, mesmo nas salas de aula, a propósito, inclusive durante a exposição dos conteúdos, ainda que nesses casos um dos ouvidos costumava permanecer vigilante dos sons ao redor. Atento? O que surpreendeu foi a tolerância com a sua trivializada onipresença: "é preferível às conversas paralelas" - ombros dados serviram qual testemunho.

Essas sobreposições panoramáticas se fazem convenientes para abordá-las na intersubjetividade de agência/mentos coletivos fardados como máquinas de guerra nos cotidianos e suas repercussões curriculantes; mas, para isso, faz-se necessário distinguir inicialmente o que tal conceito singular expressa.

Assim, ao menos dois percursos se apresentam com nitidez: um a partir dos aparelhos de projetividade sônica; o segundo, no programa de uma estratégia de guerra biotécnica mais atinente ao próprio texto musical. Em ambos os casos, como tais ações, ao perfurar performativamente os cotidianos, transmutam-se em aberturas curriculantes com a intuição de que "[...] tudo é corpo e corporal. Tudo é mistura de corpo e no corpo, encaixe, penetração" (DELEUZE, 2015, p. 90).

\subsection{Vermes e projéteis: perfurações ontológicas}

Projéteis Sonoros. Conceituação deflagrada a partir do uso de tecnologias militares de fato, em territórios civis. Sobre esse assunto, Henrique Lima (2018) empreendeu relevante tese na conta de "políticas da auralidade na era do áudio ubíquo", dedicando espaço a correlacionar certas estratégias contemporâneas de uso do som como armamento não letal, desenvolvidas sob encomenda das forças armadas dos Estados Unidos; suas apropriações questionáveis por departamentos policiais para dissuasão de protestos e manifestações em contextos urbanos; e suas desterritorializações e reterritorializações empreendidas pela indústria do 
entretenimento nos paredões de som montados em veículos automotivos que circulam nas cidades brasileiras.

Hoje, sob a alcunha de "fones de ouvido" [headphones], e já há tanto tempo contaminando os cotidianos, foram originalmente inventados pelo norte-americano Nathaniel Baldwin, que, embora tenha produzido as primeiras versões domesticamente, concebeu-os inicialmente com intuito de uso militar para a Marinha dos Estados Unidos. Curiosamente, ainda que tenha sido recomendado, Baldwin não patenteou sua ideia porque acreditou que fosse trivial.

A perfuração e capilarização observada na trama cotidianista no jogo entre táticas de uso e estratégias de mercado para consumo (CERTEAU, 2014) podem ser aqui transcodificadas como máquinas de guerra, se forem demarcadas por "práticas brandas de dispersão e aplicação de técnicas militares na vida cotidiana de populações civis" com finalidades de entretenimento (LIMA, 2018, p. 66), que, ainda que possam ser alçadas em ambos os casos à cota do abuso, nestes fins, incidem outrossim, acintosamente, vetores de intensidade desejante.

Vermes de Ouvido. Ainda no curso da pesquisa de Henrique Lima (2018), está o deslocamento de análise que ele buscou ao se distanciar dos textos sobre poluição sonora para os estudos sobre audiovirologia, cujas problematizações se debruçam sobre os "fragmentos de som que se proliferam sob a forma de produtos culturais", sejam "[...] minuciosamente programados, bem como a forma de produtos culturais feitos de modo não-profissional, e ainda por usuários de aplicativos de celulares e softwares [...] de edição de arquivos de áudio e vídeo" (LIMA, 2018, p. 70).

Dimensão adjacente pode ser notada, ainda segundo Henrique Lima, a partir de certas condições materiais capitalísticas que tornaram propícia a emergência de uma cultura viral, contexto em que "[...] o regime de produção e consumo musical baseado na Lei formal de 'tornar-se viral' faz da auralidade humana - incluindo aí audição, emoção e memória - uma via propícia para o estabelecimento de colônias virais" (LIMA, 2018, p. 71, grifo do autor). Mas essa não seria toda a história. Superpostos a essas camadas de mercado, atuariam ainda vetores de individuação relacionados à música mesmo, esta compreendida como "[...] um tipo de agente físico, porque materialmente sônico, e psicoativo, porque desempenha uma função de subjetivação, através da qual se realiza uma negociação entre pulsões inconscientes e a consciência subjetiva" (LIMA, 2018, p. 71). 
Do ponto de vista das relações em um ecossistema, esse contágio viral se vale de uma vulnerabilidade inerente ao corpo que se movimenta imerso em um meio ambiente de audição ubíqua, ao que se pode completar que são interações na ordem do ambiental, e igualmente na ordem do colonial (LIMA, 2018).

Move-se na inspiração espinoziana sentida em Deleuze e Guattari ${ }^{4}$, seguida por outros autores da audiovirologia, a "noção de campo social descrito como camadas e mais camadas de agência/mentos coletivos entre 'vetores pulsados' dotados de uma capacidade de afecção" (LIMA, 2018, p. 102). Ou seja, esses ouvidos perfurados por tais vermes seriam corpos sem uma consciência dotada de interioridade, agenciados em redes descentradas em que a cultura sônica está contagiada biotecnicamente por fragmentos locais e globais, "vetores pulsados de subjetivação [...], agentes não-humanos capazes de mobilizar o humano de modo analógico, isto é, relacionando-se diretamente com a ordem do inconsciente, do desejo, das pulsões, das compulsões [...] [espécie de] captura 'a-significante'” (LIMA, 2018, p. 102).

A captura a-significante diz sobre os significantes não restarem fixos em uma raiz linguística, mas orientados em relação ao desejo; e desejo que é coletivo, pois desejamos apenas em conjunto, coletividade essa que deseja outras coletividades (DELEUZE, GUATTARI, 2011a). Todavia, tais multiplicidades são capturas de um instante, o que diz que os significantes não são enraizados nem mesmo no desejo, ao contrário, é por intensidade desejante que os significantes se movem de apreensão em apreensão. É mesmo por isso que o desejo não reconhece a falta, porque a coletividade sempre forja um corpo que deseja no instante "[...] a positividade do corpo pleno [sem órgãos], como suporte e suposto" (DELEUZE; GUATTARI, 2011a, p. 58). E isso esboça que a escuta não se dá na busca do que falta a um corpo, para o preenchimento de um vazio, mas na aliança com o que transborda em suas intensidades aurais.

Um desses armamentos virais de compleição biotécnica disseminados, por exemplo, a partir de um hit como Bum Bum Tam Tam, e que emula todas as características anteriormente visitadas, é o assim denominado verme de orelha,

\footnotetext{
${ }^{4}$ Assim escrito em referência à seguinte passagem do primeiro capítulo de Mil Platôs: "Não chegar ao ponto em que não se diz mais EU, mas ao ponto em que já não tem qualquer importância dizer ou não dizer EU. Não somos mais nós mesmos. Cada um reconhecerá os seus. Fomos ajudados, aspirados, multiplicados" (DELEUZE; GUATTARI, 2011a, p. 17).
} 
que se refere a qualquer trecho pegajoso de música que é contínuo e mentalmente repetido por um corpo "[...] mesmo na ausência de estímulo sensorial" (LIMA, 2018 , p. 80). O autor acredita que há, nesses termos, um jogo pulsional cujo desejo atua em camadas "[...] pré-conscientes de um sistema psíquico subjetivo" (LIMA, 2018, p. 80).

Em uma órbita que gira do estético para o etológico, é imaginada uma abordagem em que seja possível deslocar o verme de orelha do debate sobre mau ou bom para uma "esfera centrada em relações de captura e contágio por afecção" (LIMA, 2018, p. 81, grifo do autor). Em tal ambiência, tanto os fones de ouvido quanto a munição biotécnica perfuram zonas de localidade ontológica e, a essa maneira, a discussão na partitura curricular pode ser notada a partir de tais ou quais "[...] táticas dedicadas à produção de surtos virais de agentes sônicos colocam em cena, também, a necessidade de elaboração de métodos práticos de relação com esse tipo de agentes replicadores" (LIMA, 2018, p. 86, grifo do autor).

Ante o exposto, é propício transduzir os projéteis sonoros e os vermes de ouvido como máquinas de guerra nos cotidianos (DELEUZE; GUATTARI, 2012b). Mas o que se quer agenciar com isso? Discutir o conceito maquínico pode ser o passo primeiro. Para a dupla francesa, essas máquinas estão destituídas de qualquer sentido mecânico, mas se distinguem como um tipo de oposição "[...] ao abstrato no seu sentido ordinário" (DELEUZE; 2012b, p. 241). As máquinas se acoplam umas às outras, dotadas de um tipo de funcionamento desejante e assim produzem/criam - e simultaneamente são produzidas e criadas - fluxo, ruptura e corte em agenciamentos coletivos, tais quais máquinas sociais, máquinas de formação, máquinas de pesquisa, máquinas comerciais etc. (GUATTARI; ROLNIK, 1996, p. 320).

Existem também as máquinas de guerra que, ao contrário do que se pode pensar em princípio, não pertencem ao aparelho de Estado, mas estão em franca oposição a este, é "[...] exterior a sua soberania, anterior a seu direito" (DELEUZE; GUATTARI, 2012b, p. 13). Seu funcionamento militar se dá no âmbito do revolucionário, da insubordinação, insurreição aos mecanismos de coerção do Estado, pois, se este constrói muros na tentativa de estriar os territórios, ao tempo em que as máquinas de guerra atuam para alisar o que intenta obstaculizar movimentos, os fluxos, será que se pode dizer, em tessitura cotidianista, que a máquina de guerra sonora atua para fender esses muros, perfurá-los para vazar suas fronteiras? 
Ao menos duas autoras do campo curricular, embora observando lugares distintos, coadunam com a ideia do currículo como uma máquina de guerra. A digressão pelos cotidianos de Janete Carvalho, Sandra da Silva e Tania Delboni (2018) abordam as redes de conversações por esse prisma, no caso, a oposição se dá ao lugar da escola na tarefa de cuidar dos negócios de Estado. Com inspiração na filosofia cartográfica, a autora percebe o pensamento mesmo como uma máquina de guerra e, a partir dele, as práticas discursivas são entendidas no intercâmbio de saber como em um tal "[...] esforço coletivo, envolvendo a participação de múltiplos agentes sociais, que direta ou indiretamente, contribuem para a melhoria das condições de vida de indivíduos e populações" (CARVALHO; SILVA; DELBONI, 2018, p. 809).

Em um viés que pode até ser difundido como pós-colonial, Ada Kroef (2001) se apoia em Félix Guattari e Suely Rolnik (1996) para afirmar que até mesmo o entendimento sobre cultura deve ser problematizado: "[...] o surgimento da concepção de cultura é produto do modo civilizacional moderno que se constitui, concomitantemente, com a transição do sistema capitalista" (KROEF, 2001, p. 101). Desse modo, deduz-se que a cultura é um constructo do capitalismo, "[...] sempre etnocêntrica e intelectocêntrica (ou logocêntrica)" (GUATTARI; ROLNIK, 1996, p. 23). Ou, de outro modo a dizer, "[...] o capital ocupa-se da sujeição econômica, e a cultura, da sujeição subjetiva” (KROEF, 2001, p. 101). Portanto, o currículo seria, nesses termos, uma máquina de guerra na produção da diferença quando concorre contra a padronização das representações perpetradas pela identidade neoliberal.

Esse é um ponto de partida para pensar as perfurações da música nos cotidianos escolares, e mais propriamente o funk, talhado na farda de guerra e acoplado a outras máquinas: projéteis sonoros e vermes de ouvido, táticas disruptivas baseadas na produção que deseja uma fuga dos territórios precários para alcançar desterritorialização. É certo que tais movimentos desterritorializantes podem ter sido, no caso específico de MC Fioti (2017), reterritorializados como viralizações culturais, mas é esse jogo intrinsecamente dual aos territórios: "[...] o espaço liso não para de ser traduzido, transvertido em um espaço estriado; o espaço estriado é constantemente revertido, devolvido a um espaço liso" (DELEUZE; GUATTARI, 2012b, p. 192).

Persistem ainda alguns ruídos a serem escutados sobre os fones de ouvido. Voltando a Henrique Lima (2018), há uma distinção entre áudio ubíquo, objeto 
central de sua pesquisa, e som ubíquo, que ecoa através da mítica panaural que todos os sons soam simultânea e permanentemente. A perspectiva que o autor prefere está mais relacionada "[...] a uma condição de infraestrutura material, particularmente aquela relativa à malha elétrica instalada sobre a face da Terra" (LIMA, 2018, p. 69), ou seja, a "[...] materialidade de vidas vividas segundo a concretude das malhas elétricas" (LIMA, 2018, p. 69).

Diante dessa paisagem, no entanto, tantas outras (sob)reposições são possíveis. Na questão em tela, mais adequadamente, interessa o tráfego de dados e a mobilidade de dispositivos de comunicação, informação e entretenimento e, portanto, de distribuição musical que tal infraestrutura permite, visto que "[...] uma quantidade imensa de pessoas desempenha sua subjetividade em relação a hábitos e em que arquivos de sons são gerados, replicados, recebidos, transmitidos", enfim, compartilhados (LIMA, 2018, p. 69).

Aliadas a esse contexto na subjetivação da ambiguidade da atenção na escuta musical pela pervasão imersiva dos fones de ouvido nas dependências da máquina escolar, a ubiquidade e a mobilidade surgem na onda de um movimento nômade; ademais, característica indefectível das máquinas de guerra, dirão até mesmo Deleuze e Guattari (2012b), em consonância ainda com o primeiro argumento, que é possível praticar o nomadismo mesmo na inércia, é o salto no bailão na simultaneidade da aula: duas escutas, uma se mantém vigilante, enquanto outra mexe com a mente e vai com o bum bum tam tam, fenda parcial no espaço-tempo da sala que permite escoamentos e tráfegos de fluxos desterritorializantes.

Assomada às autoralidades precedentes, a contribuição se daria, portanto, em uma radicalização na clave cotidianista, de modo que as narrativas com a música aqui compreendidas possam ter efeitos curriculantes performativos, cujas formas são apresentadas a seguir.

Perfuratividade streaming. As contaminações que essa tão recente ambiência digital disseminou nos modos de consumo musical e videomusical, através das tecnologias baseadas nos protocolos de streaming, parecem ter produzido uma propagação irrefreável, aí incluso todo ecossistema criativo que se conecta ao YouTube, plataforma que se tornou a segunda ferramenta de busca mais utilizada da internet, tendo como rival apenas o próprio buscador Google, ambos pertencentes à mesma megacorporação do Vale do Silício. 
No jargão tecnológico, o streaming é uma operação digital para a difusão através da internet de conteúdo multimídia por pacotes de dados em fluxo. Uma vez mais, propõe-se trazer à tona os paralelismos deleuzeanos entre corpo e texto, e da virtualidade como devir de atualização da realidade (DELEUZE, 2015; 2018): o pacote de dados em sua fractalidade é um devir-arquivo, portanto, um devir-som, devir-música; um devir-vídeo, devir-filme.

Se os fones de ouvido podem, como já foi dito, vestir local e contingentemente uma carapuça ontológica (LATOUR, 2012), a hesitação que permanecerá, no entanto, insinua-se na seguinte pergunta: é o streaming que está influenciando corpos, ou são os corpos que se expressam na tecnologia streaming? A admissão aqui é que essa tecnologia perfura para permitir conexões e acoplamentos de formasfluxos nas superfícies desejantes.

Suspendida a descrença sobre a tal hipótese, nas partituras curriculares, a perfuratividade streaming versa sobre rupturas, samples e intersecções de intensidades e potências em fluxo que escapam às capturas da máquina escolar e atravessam as brechas produzidas pelas máquinas de guerra nos cotidianos, e ao tempo encorpam agência/mentos. A apreensão será invariavelmente parcial e por pacotes de dados, que não deixam de ser outra monta de pacotes que carregam codificações, expressividades, significantes-significados e sentidos. São esses os fractais, multiplicidades acopladas à bilocalidade corpórea entre o território da sala de aula e a desterritorialização da escuta para o baile, que se difundem curriculantes.

Perfuratividade de paredão. O ribombante aparato no porta-malas de um carro seria uma aparelhagem automotiva ou uma boate ambulante? Capciosa, a pergunta acena um jogo de ambivalente que, por sua vez, também suscita movimentos e feições nomádicas.

Se na primeira camada o paredão foi apresentado como uma espécie de armamento disseminador, munição sônica e biotécnica, virologia curriculante de máquinas de guerras, aqui expõe o nomadismo aos deslizamentos entre o espaço liso e o espaço estriado, supostamente mobilizado nas (dis)tensões entre o público e o privado.

O privado será realocado no carro, aparelho sonoro como uma propriedade, não necessariamente de forja marxiana, mas a propriedade protegida legalmente pelo aparato legal do Estado, que cria uma dimensão métrica de contração e 
circunscrição positivada pela Constituição Federal; e o público - as ruas, a audição - deslocado para as linhas vetoriais e direcionais do som que, sob suas próprias leis, não pode ser contido e a efeito salta, foge e invade indiscriminadamente trajetos nos rizomas asfálticos, corpos em contato pelas superfícies. Cartograficamente, as superfícies estriadas do carro percorrem sobre as superfícies lisas da rua; máquina de guerra, o funk é disparado pela máquina da propriedade, pela proteção que Ihe estima, nada contra ela pode ser disparado, qualquer outro projétil sonoro, que não seja o seu, ricocheteia em sua redoma altissonante.

Há de se concordar que, mesmo que essa relação intrínseca ao carro-paredão seja ambígua, toda essa pressão sonora é aliança de fluxos desejantes. Mas a escola também habita a ambiguidade do corpo público e, portanto, constitui-se em território desejado para uma gama de agência/mentos sociais enquanto executa as tarefas do Estado; a coisidade pública faz parte da tarefa do Estado. Os dispositivos públicos estão atrelados ao Estado. A-significante que sejam, os agência/mentos públicos-privados fabricam uma disjuntividade a-humana; um escape do que é considerado humano, corpos e corporações sem identidade.

É nessa fronteira que a escola se faz ambiente para a simulação do baile, idas-e-vindas entre esferas pública e privada, que a partitura musical de MC Fioti (2017) invade: É a flauta envolvente / Que mexe com a mente / De quem tá presente / As novinha saliente / Fica loucona / E se joga pra gente. Nela, a dimensão da presença certamente se inscreve no público em contraste com a omissão da presença pelo que é privado, espaço háptico (Liso) naquele caso, espaço óptico (Estriado) neste: "[...] o Liso nos parece ao mesmo tempo o objeto por excelência de uma visão aproximada e o elemento de um espaço háptico (que pode ser visual, auditivo, tanto quanto tátil)" (DELEUZE; GUATTARI, 2012b, p. 217), enquanto se deve perceber, adjacentemente, que "[...] o Estriado remeteria a uma visão mais distante, e a um espaço mais óptico - mesmo que o olho, por sua vez, não seja o único órgão a possuir essa capacidade" (DELEUZE; GUATTARI, 2012b). Enfim, no que talvez não possa ser visto nem ouvido, haja um esgarçamento da presença.

A mistura entre a transversão e reversão, háptico e óptico, em Bum Bum Tam Tam, oferece problematizações: o que das novinha saliente é apenas para ser olhado na privacidade desejante das retinas, e no que pode ser tocado, quando loucona elas se joguem pra gente? Mesmo que haja aí uma mixagem, um agência/ mento curriculante pode ocorrer para tornar evidentes a "[...] distinção de direito 
[e] a distinção abstrata entre os dois espaços" (DELEUZE; GUATTARI, 2012b, p. 192) entre o corpo das novinha, mesmo que salientes, e os corpos que eventualmente os amparem, aliás, amparar deverá ser o verbo usado em substituição a agarrar, dissolução em vez de captura.

As possíveis mixagens entre háptico e óptico, dissolver ou capturar, "[...] de modo algum são simétricas, e fazem com que se passe do liso ao estriado, ora do estriado a liso, graças a movimentos inteiramente diferentes (DELEUZE; GUATTARI, 2012b, p. 192). O jogo proposto pela música pode ser praticado em partitura curricular a partir da reversão aos referenciais do Estatuto da Criança e do Adolescente (BRASIL, 1990. s.p.), que, em seu Art. 241-D, incluído em nova versão do texto no ano de 2008, proíbe "[...] aliciar, assediar, instigar ou constranger, por qualquer meio de comunicação, criança, com o fim de com ela praticar ato libidinoso", com pena de reclusão prevista de 1 (um) a 3 (três) anos, mais pagamento de multa. Ou seja, que as novinha enlouqueçam por envolvimento simbiótico com a flauta, recomenda-se que esse agência/mento seja capturado parcialmente, ou seja, que os significantes orientados pelo desejo sejam contidos na ordem do privado-óptico.

Dessa forma, pensar movimentos de transversão e reversão dos fluxos investidos pelas perfuratividades do paredão sonoro contra os muros da escola, na simbiose com a presença pública e no que se hospeda nos privados aposentos do desejo; do háptico e do óptico, ou seja, do que se toca e do que se pode tocar; do que, por direito, não pode passar do alcance de uma produção do olhar fabulada pela visão, enfim, pode vir a compor uma partitura curricular.

\section{PARTITUROGRAFAGENS}

Se as seções anteriores se situaram mais no plano de uma conceituação sobre um currículo perfurativo, esta última foi composta com o intuito de criar um programa de prospecção curriculante com os personagens conceituais que emergiram ao longo desta partitura, para criar um certo nexo funcional; isso posto, dado que Deleuze e Guattari (2010) são ciosos da premissa de que, se à filosofia cabe criar conceito, resta à ciência produzir função e prospecção, e à arte, as sensações. Decerto a intenção da nossa pesquisa é a de se situar nessas intersecções, e é tanto por essa localidade que, para além de conceituar, as partiturografagens a seguir premeditam, em tonalidade aforística, possíveis pautas para um currículo perfurado pelo funk em cotidianos escolares. 
Um currículo-funk é uma máquina de guerra que se produz em programa tático; seu funcionamento é parcial porque se dirige a fabricações de entrelugares; isso porque joga contra as estratégias hegemonizadas, mas contando com armas contaminadas pelos discursos hegemonizados; não se consegue derrotar as alteridades coloniais nunca em definitivo, o currículo-funk ocupa territórios em batalhas de desterritorialização de alteridades coloniais; a projetividade musical pública programada como prática construção de espaços escolares é uma dessas armas, cuja playlist pode ser produzida em negociações entre produções de cultura viral [colonial] e apostas musicais pós-coloniais; deve-se considerar que cada playlist tática é uma batalha vencida em uma vitória sempre adiada.

O currículo-funk considera que um produto cultural viral é uma colonialidade viral, ou seja, um agência/mento contagiado por multiplicidades coloniais dispersadas; significantes, significados e sentidos virais [coloniais]; os cotidianos escolares, então, são ambientes propícios à viralização; o que carrega o currículo para um programa ecológico de regulação viralidade [colonialidade], que se inicia na própria partitura curricular no cultivo de discursividades pós-coloniais como agência/mentos polinizadores em práticas cotidianas, cultivo da diferença para conter pandemias; é uma ecologia do currículo.

Questão sem resposta: seria possível viralizar composições de contra-hegemonia colonial, ou a viralidade é um significante intrínseco à colonialidade? Retroviralidade é uma aposta no cultivo; cultivar currículos é cuidar para que a linguagem cultural como expressão capitalística globalizada de controle sobre as subjetividades seja regulada; cultivo é sobre cuidado e defesas; cuidar em cultivo é sobre plantar, regar, colher, mas também cortar e mobilizar defesas contra agentes invasivos; isso pode ser feito no âmbito discursivo no texto do currículo escolar, plantar palavras com significantes e sentidos locais, e podar palavras de homogeneização globalizante, produzir máquinas de guerra.

A polinização musical também pode ser uma alternativa às armas de projetividade de alta pressão sonora; isso se faz em aliança com os dispositivos de mobilidade, pervasão e ubiquidade tecnológica: celulares, tablets, fones de ouvido e caixinha Bluetooth; o comportamento streaming pode ser agenciado como potência produtiva conectada a ferramentas digitais na produção de podcasts e videocasts com formas e conteúdos localizados; a tolerância aos fones de ouvido em sala de aula e a pactuação com bilocalidade são oportunidades de negociar com a audiência. 
Mesmo aqui, polinização se faz com conteúdo e uma playlist negociada; em um currículo perfurado pelo funk, o conteúdo didático não é disseminado integralmente em sala de aula, mas fracionado e polinizado em uma fronteira de escuta bilocal; mesmo as aulas poderiam ser mais curtas, se parte do conteúdo didático fosse streaming; e é através mesmo das produções por e com agência/ mentos locais que se faz a escuta institucional intercambiar com os desejos que transbordam esse lugar nos cotidianos; embora um currículo mais explicitamente cotidianista tende a fazer curriculantes a escuta dos desejos através das músicas já disseminadas nos espaços escolares; ou seja, uma rede de agência/mentos curriculantes com a música já acontece, cabe acolhê-los com uma escuta negociada.

Como defesa contra práticas de abuso sexista, o currículo deve cultivar discursos preventivos aliados a práticas didáticas com músicas de características retrovirais, que podem ter como ponto de partida a própria performance em Grupos de Experiência (GE); mas, igualmente, uma programação musical e informativa para podcasts e videocasts com produção local em cotidianos pode ser uma boa gestão preventiva.

\section{REFERÊNCIAS}

BARBA, Eugênio. A canoa de papel: tratado de antropologia teatral. Tradução de Patrícia Alves. São Paulo: Editora HUCITEC, 1994.

BHABHA, Homi. O local da cultura. Belo Horizonte: Editora UFMG, 2013.

BRASIL. Lei n. 8.069, de 13 de julho de 1990. Dispõe sobre o Estatuto da criança e do adolescente e dá outras providências. Brasília, DF, 1990. Disponível em: http://www. planalto.gov.br/ccivil_03/leis//8069.htm. Acesso em: 17 jul. 2020.

BUTLER, Judith. Corpos em aliança e a política das ruas: notas para uma teoria performativa de assembleia. Rio de Janeiro: Civilização Brasileira, 2018.

CARVALHO, Janete M.; SILVA, Sandra Kretli; DELBONI, Tania Mara Zanotti Guerra Frizzera. Currículos como corpos coletivos. Currículo sem Fronteiras, Rio de Janeiro, v. 18, n. 3, set./dez. 2018. Disponível em: http://www.curriculosemfronteiras.org/vol18iss3articles/ carvalho-silva-delboni.pdf. Acesso em: 14 jul. 2020.

CASTELLS, Manuel. A galáxia da internet: reflexões sobre a internet, os negócios e a sociedade. Tradução de Maria Luiza X. de A. Borges. Rio de Janeiro: Zahar, 2003. 
CERTEAU, Michel. A invenção do cotidiano: 1. artes de fazer. 22. ed. Tradução de Ephraim Ferreira Alves. Petrópolis: Vozes, 2014.

COSTA, Rogério. A improvisação livre não é lugar de práticas interpretativas. Debates, Rio de Janeiro, n. 20, p. 177-87, maio 2018.

DELEUZE, Gilles. Diferença e repetição. Tradução de Luiz Orlandi e Roberto Machado. Rio de Janeiro/São Paulo: Paz e Terra, 2018.

DELEUZE, Gilles. A lógica do sentido. Tradução de Luiz Roberto Salinas Fortes. São Paulo: Perspectiva, 2015.

DELEUZE, Gilles; GUATTARI, Félix. Mil platôs: capitalismo e esquizofrenia. 2. ed., 2. Reimp. Tradução de Aurélio Guerra Neto, Ana Lúcia de Oliveira e Lúcia Cláudia Leão e Suely Rolnik. São Paulo: Editora 34, 2012a. (Coleção Trans, v. 3). 128 p.

DELEUZE, Gilles; GUATTARI, Félix. Mil platôs: capitalismo e esquizofrenia. 2. ed., 1 reimp. Tradução de Peter Pál Pelbart e Janice Caiafa. São Paulo: Editora 34, 2012b. (Coleção Trans, v. 5). 264 p.

DELEUZE, Gilles; GUATTARI, Félix. Mil platôs: capitalismo e esquizofrenia. 1. ed., 2. reimp. Tradução de Aurélio Guerra Neto e Célia Pinto Costa. São Paulo: Editora 34, 2011a. (Coleção Trans, v. 1). 94 p.

DELEUZE, Gilles; GUATTARI, Félix. Mil platôs: capitalismo e esquizofrenia. 2. ed., 2. reimp. Tradução de Ana Lúcia de Oliveira e Lúcia Cláudia Leão. São Paulo: Editora 34, 2011 b. (Coleção Trans, v. 2). 128 p.

DELEUZE, Gilles; GUATTARI, Félix. O que é a filosofia? 3. ed. Tradução de Bento Prado Jr. e Alberto Alonso Muñoz. São Paulo: Editora 34, 2010.

DERRIDA, Jacques. Gramatologia. Tradução de Mirian Schnaiderman e Renato Janini Ribeiro. São Paulo: Perspectiva, 1973.

ESTEBAN, Maria T. Dilemas para uma pesquisadora com o cotidiano. In: DUARTE, Regina Leite (Org.) Método: pesquisa com o cotidiano. Rio de Janeiro: DP\&A Editora, 2003.

FIOTI, Mc. Bum Bum Tam Tam. São Paulo: KondZilla, 2017. Streaming (2'50"). Disponível em: https://youtu.be/_P7S2IKif-A. Acesso em: 10 set. 2021.

GUATTARI, Félix. Caosmose: um novo paradigma estético. 1. ed. Tradução de Ana Lúcia de Oliveira e Lúcia Cláudia Leão. São Paulo: Editora 34, 1992. 
GUATTARI, Félix; ROLNIK, Suely. Micropolíticas: cartografias do desejo. 4. ed. Petrópolis: Vozes, 1996.

HIMANEN, Pekka. La ética hacker y el espírito de la era de la información. [S.I.]: [s.n.], 2001. Disponível em: http://eprints.rclis.org/12851/1/pekka.pdf. Acesso em: 24 jun. 2019.

JESUS, Rosane Meire Vieira; OLIVEIRA, Iris. Grupo de experiência e arte. In: MACEDO, Elizabeth; TOMÉ, Cláudia. (Org.). Currículo e diferença. 1. ed. Curitiba: CRV, 2018. p. 171-88. V. 4.

KROEF, Ada B. G. Interceptando currículos: produzindo novas subjetividades. Educação \& Realidade, Porto Alegre, v. 26, n. 1, jan./jul. 2001. Disponível em: https://seer.ufrgs.br/educacaoerealidade/article/view/41317. Acesso em: 14 jul. 2020

LATOUR, Bruno. Reagregando o social: uma introdução à Teoria do AtorRede. Salvador: EDUFBA, 2012.

LIMA, Henrique R. S. Desenho da escuta: políticas da auralidade na era do áudio ubíquo. 2018. Tese (Doutorado em música) - Universidade de São Paulo, São Paulo, 2018.

LOPES, Alice C.; MACEDO, Elizabeth. Teorias do currículo. São Paulo, Cortez, 2011.

MATURANA, Humberto. Cognição, ciência e vida cotidiana. Tradução de Cristina Magro e Victor Paredes. Belo Horizonte: Editora UFMG, 2001.

RANNIERY, Thiago. Corpos feitos de plástico, pó e glitter: currículos para dicções heterogêneas e visibilidades improváveis. 2016. 411 p. Tese (Doutorado em Educação) - Universidade Estadual do Rio de Janeiro, Rio de Janeiro, RJ, 2016.

ST. PIERRE, Elizabeth. Post Qualitative Inquiry in an Ontology of Immanence. Qualitative Inquiry, Thousand Oaks, v. 25, n. 1, p. 3-16, 2019.

ST. PIERRE, Elizabeth. Uma história breve e pessoal da pesquisa pós-qualitativa. Práxis Educativa, Ponta Grossa, v. 13, n. 3, p. 1044-64, 2018.

ZÉ, Tom. O gênio de Irará. Encarte. Caros Amigos, São Paulo, n. 31, out.1999. 


\section{Sobre os autores:}

Augusto Flávio: Doutorando em Educação Universidade Federal da Bahia (UFBA). Mestre em Educação pela Universidade do Estado da Bahia (UNEB), campus XIV. Pedagogo pela UNEB, campus VIII. E-mail: augustofroque@gmail.com, Orcid: https://orcid.org/0000-0002-1143-1848

Rosane Meire de Vieira de Jesus: Doutora em Educação pela Universidade Federal da Bahia (UFBA). Mestra em Educação e Comunicóloga pela UFBA. PróReitora de Extensão e professora do Programa de Pós-Graduação em Educação e Diversidade (MPED) Campus XIV da UNEB. E-mail: rosanevieiraj@gmail.com, Orcid: https://orcid.org/0000-0003-0330-1338

\section{Recebido em: 08/09/2021}

Aprovado em: 01/10/2021 